person suffering from chronic alcoholism be regarded as a patient, such habitual drunkard, whether he has committed a slight or a serious criminal offence or not, should equally be treated as a patient. Now as these alcoholists cannot be placel under a suitable régime in a lunatic asylum, and, moreover, as the other patients in the lunatic asylum suffer in many ways fron intercourse with alcoholists, it becomes the duty of the State to construct separate asylums in which habitual drunkards-i.e., persons suffering from chronic alcoholism-should be confined for a sufficiently long period-let uss sav two years - and should be properly treated and fically discharged as cured or should be transferred to a lunatic asvlum for permanent care and treatment. We will leave out of this discussion the point whether the State should to a certain extent be made liable for the maintenance of families of habitual drunkards or be charged with the administration of the property of habitual drunkards during the period of retention. 'The State must, however, in the end adopt the only actmissible stanripoint namely, that of humanity and science. A habitual rrunkard suffers from brain disease and, in common with other lunatics, must be treated as a patient. Now, a patient recognised as insane does not require to have committed a criminal nffence in order to qualify for reception into a lunatic asylum and thereby to participate in the care and treatment of the asylum anthorities. Why, therefore, should the case of a habitual drunkard who also suffers from brain disease be regarded in a different light? 'The Bill introduced on April 25th last can only become a complete success and be recognised as an important artvance in scientific legislation if it ceases to be confiner to the cases of criminal habitual drunkards and is extencled to the cases of all habitual drunkards, being persons respectively aftlicted with a psvchical defect. In that wav alone the final ethical object of the Habitual Drunkards Act can be attained, which should consist in diminishing the total number of individuals lost to the State through immoderate use of alcobol and in restoring: a very great number of habitual irunkards to their respective occupations-that is, by curing them.

I am, Sirs, yours faithfully,

DIRECTOR SCHLANGENHAUSEN.

Velden, Austria, June 8th, 1898.

\section{THE BRAVERY OF SURGEON-LIEUTENANT HUGO.}

To the Editors of THE LANCET.

SIRs,-Commenting on your report of the speech made by Surgeon-Major-General Jameson at the annual dinner of the Indian Medical Service, in which, amongst other important matters, he refers to the heroic action of Surgeon-Lieutenant Hugo, who saved the life of a brother officer at the imminent risk of sacrificing his own, it must occur to all loyal medicals that such a service should not go without its reward, and I feel sure that there are those medical Members in the House of Commons (alas! few though they be) who, if approached, would gladly bring this matter prominently to the notice of the House and so be the means of assisting the officer to obtain that which alone he cannotthe V.C. decoration, which his commanding officer has said he so richly deserves.

Shrewsbury, July 4th, 1898. I am, Sirs, yours faithfully, ED. Cureton.

\section{COMPENSATION IN AORTIC REGURGITATION \\ To the Editors of THE LANCET.}

SrRs, - The measurements $\mathrm{I}$ have made of the last tracing taken on May 27th of my case of aortic regurgitation have brought to light a source of error in the former tracings which must at once he corrected. Carefully as the earlier ones were taken, so that I thought there was no possibility of mistake, I am now convinced that the earlier tracings are of a reversed type and that the measurements of duration of systole in the later tracing are much more near the normal. The later measurements show : duration of systole $0.36 \mathrm{sec}$., duration of diastole 0.56 sec.. heart radial delay 0.20 sec., and pulse rate 0.69 per minute.

While, therefore, conclusively showing that in this case of pure aortic regurgitation there is certainly no diminution of the heart radial interval $I$ must withdraw, the "evidence I have setforth as to compensation by increased peisistence of systole. It is true that the systole is slightly prolonged for the pulse-rate in question, but the point 1 wished to emphasise is not proven and has to be further investigated. The patient, a young man, aged thirty-six years, is now feeling quite well and is able to go fly-fishing and to play lawn tennis, \&c., but the nature of the beneficial compensation mobably does not lie chiefly in a prolongation of the cardiac systolic time, seeing that the prolongation is so slight.

Hereford, Juls 2nd, 1898. I am, Sirs, yours faithfully,

\section{THE LATE DR. BLUNT.}

To the Editors of THE LANCET.

SIRs.-There is a slight error in your obituary notice in 'THE LANCE' of June 25th of $1 \mathrm{yy}$ old friend the late Dr. Blunt of Birmingham which it may be well, in memory of old associations, to correct. You say that he was never connected with any of the hospitals or public institutions of the town. For one summer session-I think it was in 1860--Dr. Blunt filled the chair of Forensic Medicine in Queen's College, and for a still shorter time he held the office of Dean of Faculty in that institution. I wa his colleague at the time as a Professor in the College ant followed him as Dean. It was a time of storm and stress in the history of that institution, for which Dr. Blunt was by his tone of mind not well adapted. Had he been able to retain his connexion with the College its subsequent history might have been very different. Enless, too, my memory plays me false Dr. Blunt was, if not the editor, at least the leading spirit, in the conduct of the Midland Quarterly Journal of Medieal science, which harl a brief bnt not an inglorions career, and in which he was largely assnciated with another old colleagne of mine, the late Dr. Heslop. whose memory is, I have no doubt, still cherished by many in the Midlands.

$$
\text { I am, Sirs. yours faithfully. }
$$

Gloucester.

Francis T. Boxd, M.D. Lond.

\section{"THE ALLEGED DEARTH OF QUALIFIED ASSISTANTS."}

To the Editors of THE LANCET.

SIRs,-Allow me to attempt to depict the reverse sirle of the picture. In the first place, let me explain that after serving as medical officer and house surgeon in several institutions I took an assistancy in the country obtained by the rery simple means of giving my name to a wholesale house of druggists. I was offered, and accepted, the salary of $£ 80$ (incloors). I was treated in every way as one of the family, was allowed a free hand with ny patients, did a share only of the midwifery, dispensing, book-keeping, \&c., and lived far better than I have ever been in a position to live since. I then took a small practice of my own for three vears and was at the end of that time recalled by my former employer as partner. During my assistancy my employer's expenses were somewhat as follows: horses, $£ 100$; two orooms, $£ 100$; my own salary and board, $£ 120$; drug bill, $£ 50$; rent, $£ 45$; rent of surgery, $£ 10$; making a total of $£ 425$. His income might be averaged at $£ 700$ and he was expected to subscribe liberally to everything. I had absolutely no necessary expenses except clothing. Who was in the better position at the time-ny employer with a reduced income of $\$ 275$, on which to maintain a wife and family, two servants, \&c., or myself with a fixed salary and no one to maintain? Of course, the thing could not have been done without private means and vet one man alone could not possibly have done the work. 'Then take my present position. I am in practice and in receipt of an incone of about $£ 400$, to earn which I work practically night and day. I pay a rent of $£ 35$, keep two horses and a groom, and have a drug bill of abowt $\$ 40$. I never get a holiday and want an assistant bally, but how on earth is ho to be paid? Possibly the practice might increase to $£ 600$, but there would be extra horses necessary in a wide country district as well as the assistant's salary.

An Assistant" writing on June 29th must be either a wit or an epicure. Caterpillars cooked among vegetables I have seen at the best houses and are at times quite unavoid able; the presence of "flies in heer" proves, at all events, 